成層化した流水中へ放出される鉛直重力噴流の数值シミュレーション

Numerical Simulation of Vertical Forced Plumes in Stratified Cross Flow

(財) 電力中央研究所 正員 水 鳥 雅 文

(財) 電力中央研究所 正員 片 野 尚 明

(財) 電力中央研究所 正員和田明

1. はじめに

本研究で対象とする現象は, 水深 $\mathrm{H}$ と放出口直径 $\mathrm{D}$ と比 $\mathrm{H} / \mathrm{D}$ が極めて大きい条件下における鉛直重力 噴流の拡散過程である。乙のような拡散現象は, 重力噴流自身の放出条件とともに, その放出される場（周 囲流体）の状態によって様々に変化する。例えば一般の海象条件を考えると, 海水の流れや水温成層の存在 がその拡散挙動に大きく影響するあのと考えられる。特に夏季沿岸海域では, これらの要因が共存するとい ったきわめて複雑な状況も想定される。

こうした複雑な周囲水環境下における重力噴流の拡散過程を解析するためには, 従来から広く用いられて いる連行現象の概念に基づいた簡便な常微分型のモデルよりも, 流体力学と物質拡散に関する基本方程式群 を直接数値解析する手法の方がより様々な条件に柔軟に対応でき, より精度の高い解析手法であると考えら れる。

そこで本研究は, 複雑な周囲条件に放出される重力噴流現象に対して 3 次元モデルによる数值シミュレー ション解析手法を実用的なレベルに到達されることを目的として, 以下の 3 種類の周囲条件で検討を実施す る。まず, その拡散過程がほぼ解明されている(1)静水・成層域および(2)流水・非成層域について, 数値解析 結果と筆者らの実験結果ならびに既往の研究成果との比較・検討を行って, 本手法の適用性と問題点を明確 化する。ついで, 周囲条件が最む複雑でその拡散過程がまだ十分に把握されていない(3)流水・成層域での鉛 直重力噴流について数值シミュレーションを実施し，その拡散特性について若干の考察を行う。

2. 基本方程式

本研究で用いる数理モデルの基本方程式は以下の通りである。ただし，熱量と塩分の両保存式が存在する のは, 放出水と周囲水との密度差は塩分で, 周囲水成層場は温度によって各々形成されていると想定してい るためである。

（連 続 式） $\frac{\partial \mathrm{ui}}{\partial \mathrm{xi}}=0$

(運動方程式) $\quad \frac{\partial \mathrm{ui}}{\partial \mathrm{t}}+\frac{\partial}{\partial \mathrm{xj}}(\mathrm{ui} \cdot \mathrm{uj})=-\frac{1}{\rho} \frac{\partial \mathrm{P}}{\partial \mathrm{xi}}-\mathrm{g} \frac{\Delta \rho}{\rho} \delta_{3 \mathrm{i}}+\frac{\partial}{\partial \mathrm{xj}}\left(\varepsilon_{\mathrm{mj}} \frac{\partial \mathrm{ui}}{\partial \mathrm{xj}}\right)$

（熱量保存式） $\frac{\partial \mathrm{T}}{\partial \mathrm{t}}+\mathrm{ui} \frac{\partial \mathrm{T}}{\partial \mathrm{xi}}=\frac{\partial}{\partial \mathrm{xi}}\left(\varepsilon_{\mathrm{Ti}} \frac{\partial \mathrm{T}}{\partial \mathrm{xi}}\right)$

（塩分保存式）

$$
\frac{\partial \mathrm{S}}{\partial \mathrm{t}}+\mathrm{u} \mathrm{i} \frac{\partial \mathrm{S}}{\partial \mathrm{xi}}=\frac{\partial}{\partial \mathrm{xi}}\left(\varepsilon_{\mathrm{Si}} \frac{\partial \mathrm{S}}{\partial \mathrm{xi}}\right)
$$

（密 度 式） $\rho=\rho_{\mathrm{S}}(\mathrm{T}, \mathrm{S}) \quad($ 例えば, クヌードセン式)

ここで, $\mathrm{xi}, \mathrm{ui}$ : 直交座標軸と速度成分（ $\mathrm{i}, \mathrm{j}=1,2,3), \mathrm{T}:$ 温度, $\mathrm{S}:$ 塩分, $\mathrm{P}:$ 圧力, $\varepsilon_{\mathrm{mi}}:$ :渦動 粘性係数, $\varepsilon_{\mathrm{T}}, \varepsilon_{\mathrm{Si}}$ : 温度, 塩分の渦動拡散係数, $\rho, \triangle \rho$ : 密度および密度差, $\rho \mathrm{s}:$ 参照密度。 ただし, 静水・成層域の場合には，その拡散が軸対称的現象であるため，上記の式を円筒座標系（r-z 系）に変換して取り扱うこととした。 
3. 計算諸条件と計算手法の検討 前述の基本式をむとに実際現象 をシミュレーションするにあたっ ては，適切な諸条件の設定抢よび 計算手法の選択が重要となる。以 下にてれらの点について検討した 結果を示す。

（1）渦動粘性係数之渦動拡散係数 本研究では基本的にプルームの 半值半幅を混合長とした混合距離 モデルをあとに設定する。具体的 には表- 1 亿示すように各計算領域毎に設定値を変化させる ことにより良好な計算結果を得た。主な設定上の留意点は, (静水域中のプルーム内渦動粘性係数は, 放出口近傍の噴流領域に 比べそれ以遠の領域の方が乱れの発達が予想されるため, 検討の結 果式中の定数值を噴流領域の 1.5 倍とした。①乱流シュミット数は 0.7 とほぼ既往の研究結果 ${ }^{2)}$ と同程度の值が適当であった。@初期 設定温度成層を保持するために，成層境界面近傍での鉛直方 向渦動拡散係数を $10^{-5} \mathrm{~m}^{2} / \mathrm{s}$ 程度に設定する，等である。 （2）境界条件

本計算で用いた境界条件は図－1亿示すとおりである。水 表面の境界条件については, 別途水位上昇を認めた自由境界 での計算を実施し，今回の放出条件では水位上昇の影響は小 さいととを確認したため，乙こでは固定境界とした。

(3) 初期条件の計算手順

初期条件を設定するための計算手順は以下の通りである。

（i）成層域の場合, $\mathrm{u}=\mathrm{v}=\mathrm{w}=0, \mathrm{P}=0$ として初期設定水 温分布から圧力分布を計算する。圧力計算法としては, HSMAS 法を用いた。なお精度を確認するために poisson 方程式より求める方法につい てあ検討したが，両者の間に 有意な差は認められなかっだ。 （ii）流水域の場合，(i)とは別 途汇密度差を考慮せず，場の 流動と放水流動を計算する。 (iii) 静水・成層域の場合には (i)で求めた圧力分布を初期圧 力場として放水流動計算を開 始する。

(iv) 流水 - 非成層域の場合に は(ii)で求めた流速・圧力分布 を，流水・成層域の場合には

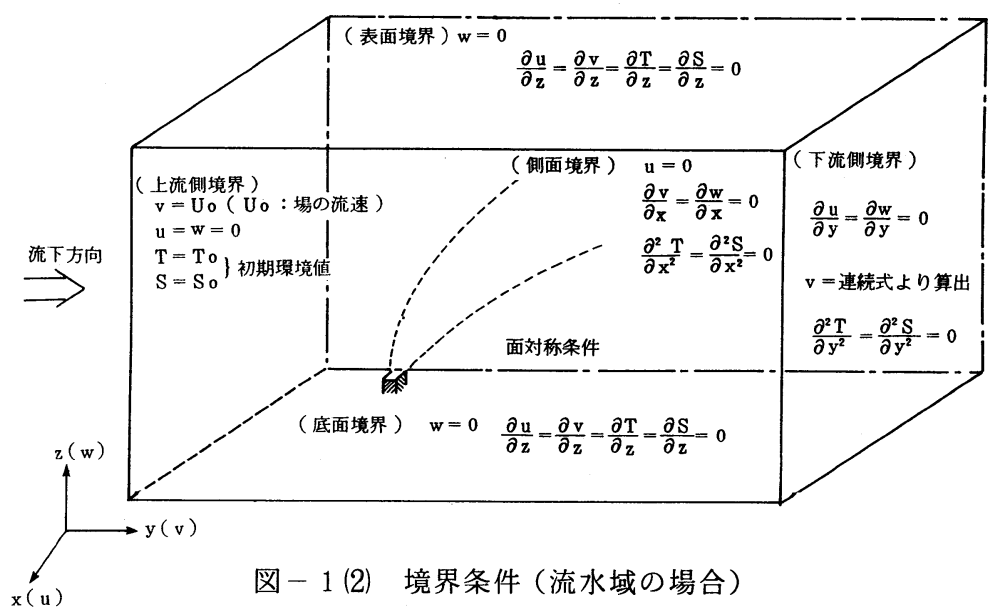


これに(i)で求めた圧力分布を加え，乙れを初期条件として全方程式による計算を開始する。

(4)メッシュ分割

静水域の場合には軸対称現象と考えられるため $\mathrm{r}-\mathrm{z}$ 平面, 流水域の場合には放出口中心を含む縌断面で 面対称と考えられるため中心断面から片側を計算領域に設定する。

メッシュ分割は，プルームの拡がり幅に応じて狭い所ほど細分割する必要があるため，ててでは不等間隔 メッシュを採用した。計算格子点数は, 静水域の場合 736 点, 流水域の場合 35,568 点である。

\section{4. 計算結果とその考察}

前述の数值モデルを用い, (1) 静水・成層域, (2)流水・非成層域, (3)流水・成層域の 3 種類の周囲水条件下 における鉛直重力噴流拡散現象の数值シミュレーションを実施した。こてで取り扱う重力噴流は, 海面下

$21.5 \mathrm{~m}$ 亿位置する直径 $5 \mathrm{~cm}$ の円形放出管より初期流速を $7 \mathrm{~m} / \mathrm{s}$ で放出されるという条件を想定する。放出 水は淡水, 周囲水は塩 水とし, 両者の密度差

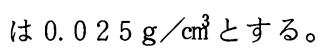

以下にシミュレーシ ョン結果の概要を示す。

（1）静水 - 成層域の場 合

周囲水の成層条件は 2 成層型の温度成層と し, 上下層の温度差 2 ${ }^{\circ} \mathrm{C}$, 上層厚さ $5 \mathrm{~m}$ 之設

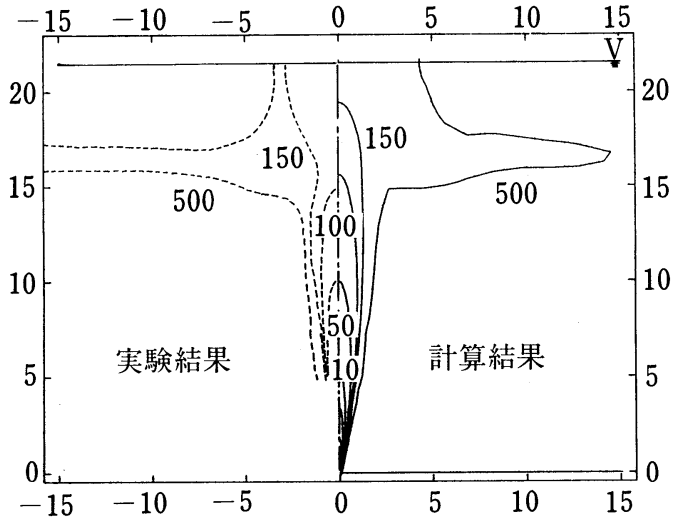
定した。

図 -2 は, 放出水濃 図 -2 放出水濃度の縦断面分布（静水・成層域） 度（塩分濃度に対応）

の縦断面分布について計算結果と筆者らの実施した実験結 果との比較を示す。放出水は運動量によって一旦水表面に 到達した後, 負の浮力によって放出水と等密度を有する成 層境界面付近に沈降していく拡散形態が両者よく一致して いるものと認められる。

図ー 3 には流速ベクトル縦断面分布の計算結果を示す。 プルーム上昇域执よび水平拡散領域に扣ける周囲水の連行 加入の様子が明瞭に読み取れる。

図一 4 は, プルーム中心に沿った放出水濃度の希釈倍率 および流速低減率の変化に関して, 上述の計算結果ととも に別途実施した非成層条件下での計算結果ならびに Abraham の実験式を示す。乙れらを比較すると, 希釈倍率およ び流速低減率ともに, 今回の計算では水表面近くまではほ ぼ非成層域の場合と同様に変化し, Abraham の実験式と よく一致していると認められる。ただし，流速低減率の変 化を見ると, 成層化している場合の方が水表面近くでの急 速な流速の減衰がより潜った所に出現していることがわか る。

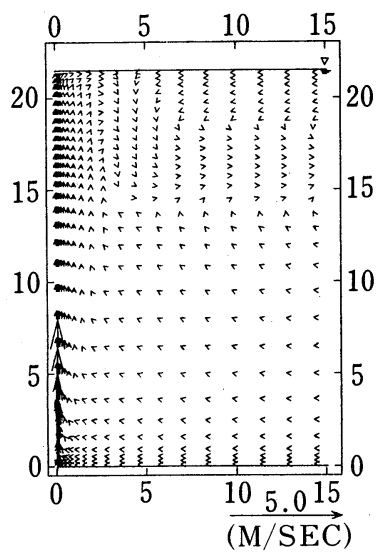

図ー3 流速ベクトルの縦断面 分布（静水・成層域）

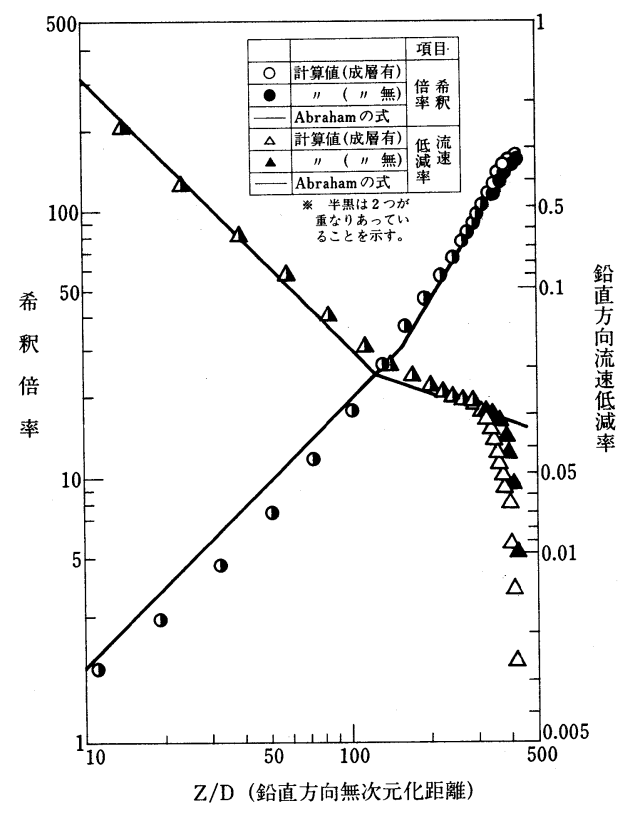

図一－プルーム中心の希釈特性, 流速低減特性の比較 


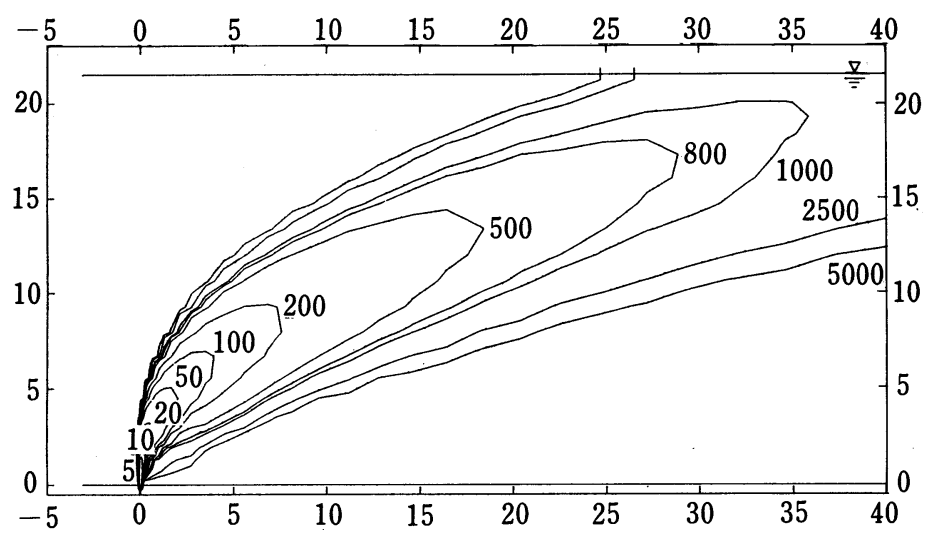

(1) 縦断面分布

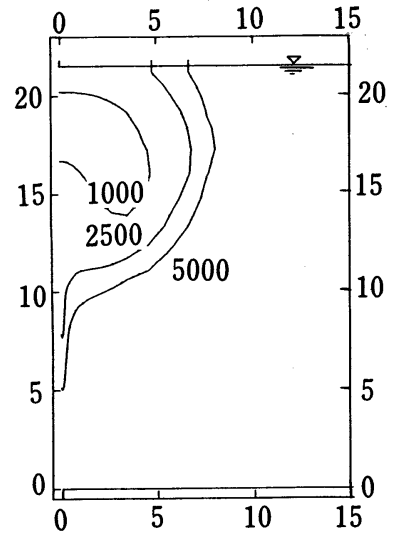

(2) 横断面分布 $(y=29.62 \mathrm{~m})$

図-5 放出水濃度分布（流水・非成層域）

（2）流水・非成層域の場合

周囲水の条件は $10 \mathrm{~cm} / \mathrm{s}$ で全域一様と設定した。

図ー 5 には放出水濃度のプルーム中心に沿った縦断面分布およ び横断面分布の一例を, 図一 6 にはその横断面内の流速べクト ル分布を示す。放出水が周囲流速によって次第に曲げられてい く様子, 下方向からの周囲水の連行加入, および既往の研究 4 亿 おいても指摘されている横断面分布の馬蹄形への変形が認めら れる。

図ー7は,プルーム中心の経路および希釈特性について計算 結果と先に筆者らが提案した実験式との比較を示す。経路につ いては両者は良い一致を示している。一方, 希釈特性について みると, 水表面近くを除いて全体の変動はほぼ同一傾向を示す

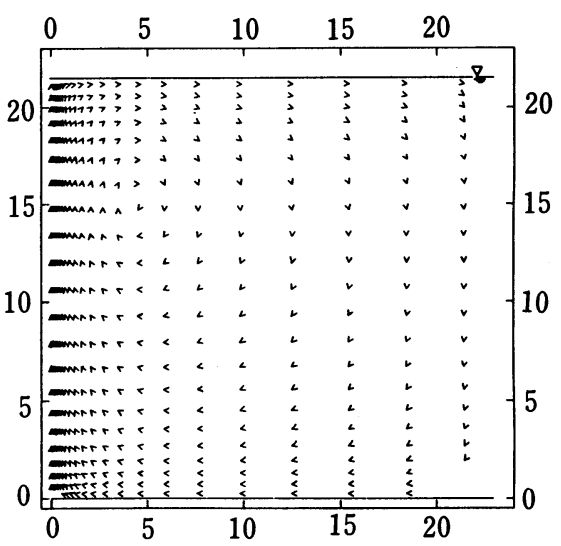
あのの，希釈倍率の計算値は全体的に実験式の值を下回ってい図一6 流速べクトル横断面分布 $(\mathrm{y}=29.62 \mathrm{~m})$ る。乙の相違に関する計算上の問題点としては, (1)円形 の放出口をその直径 Dを一辺とする正方形形状に置き換 えている点, (2)渦動粘性・拡散係数の設定法, 等が考え られる。参考のため, 図-7 中には一辺Dの正方形と同 面積となる円形放出口を想定し, その直径 $\mathrm{D}^{\prime}(=2 \mathrm{D} / \sqrt{\pi})$ で計算結果および実験式を整理し直した結果を示してい る。これによると両者の差は若干縮小する傾向にあるこ とがわかる。今後, 乙の希釈特性の相違についてはさら に検討を加えていく予定である。

以上の(1)および(2)の結果より，本報で用いた数値モデ ルは成層条件下および流水条件下における鉛直重力噴流 に十分適用できると判断される。

（3）流水・成層域の場合

次に, 上述の 2 つの要因が共存する条件下に括ける数 值シミュレーションを実施した。成層および流水条件は

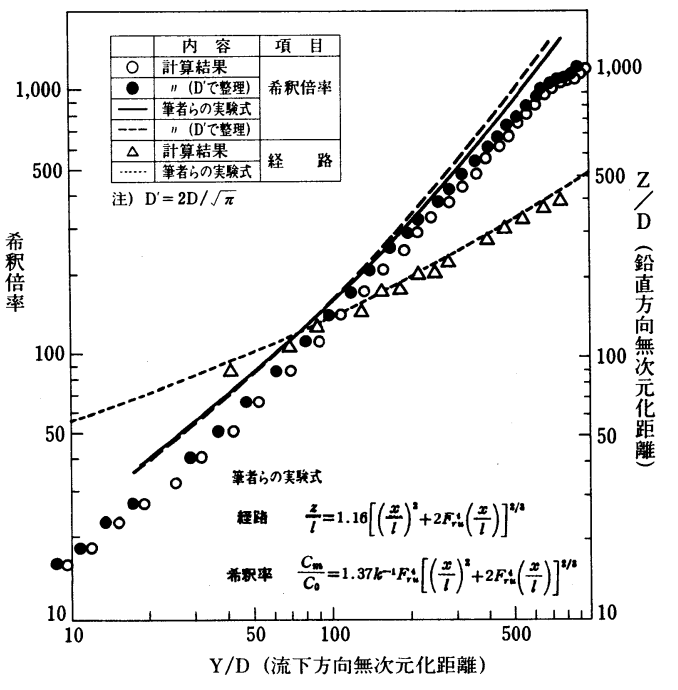

図ー7 プルーム中心の経路, 希釈特性の比較 
(1)，(2)と同様である。すなわち， 2 成層型の温度成層場（厚さ $5 \mathrm{~m}$, 温度差 $2{ }^{\circ} \mathrm{C}$ ）で全域一様の $10 \mathrm{~cm} / \mathrm{s} の$ 流動場を与えた。

図-8には, 放出水濃度のプルーム中心に沿って縦断面分布を示す。てれより, 放出されたプルームが成 層の影響により水表面へ向う上昇が抑制され，成層境界面付近から水平方向へ拡散していく形態となるとと が特徵的に認められる。

また, 図-9には放出水濃度の横断面分布形状の変化を示す。放出直後は楕円形をしていた分布形状が流 下方向に移行するにつれて低希釈倍率 (高濃度) の領域から徐々に馬蹄形に変化し，その変化が非成層域の 場合よりあ明瞭に表われ，プルームの分岐現象へと発達していく様子がうかがえる。

図一 10 は, 放出口近傍拈よび成層境界面到達後の横断面流速ベクトル分布を示す。噴流内への周囲水の連 行状況について両者を比較すると, 放出口近傍では噴流の下方からのみ連行しているのに対し, 成層境界面 到達後では上下 2 方向からの連行がある点が注目される。これは, 前述の非成層域の場合（図一 6 参照）に は認められない現象であり, 上述の横断濃度分布形状の変化特性と対応して考えることができる。

図-11にはプルーム中心に沿った希釈特性, 噴流幅および厚さについて, 本計算結果と前述の流水・非成 層域の計算結果とを比較したものを示す。希釈特性は，水表面付近でわずかな相違が認められるすのの概ね

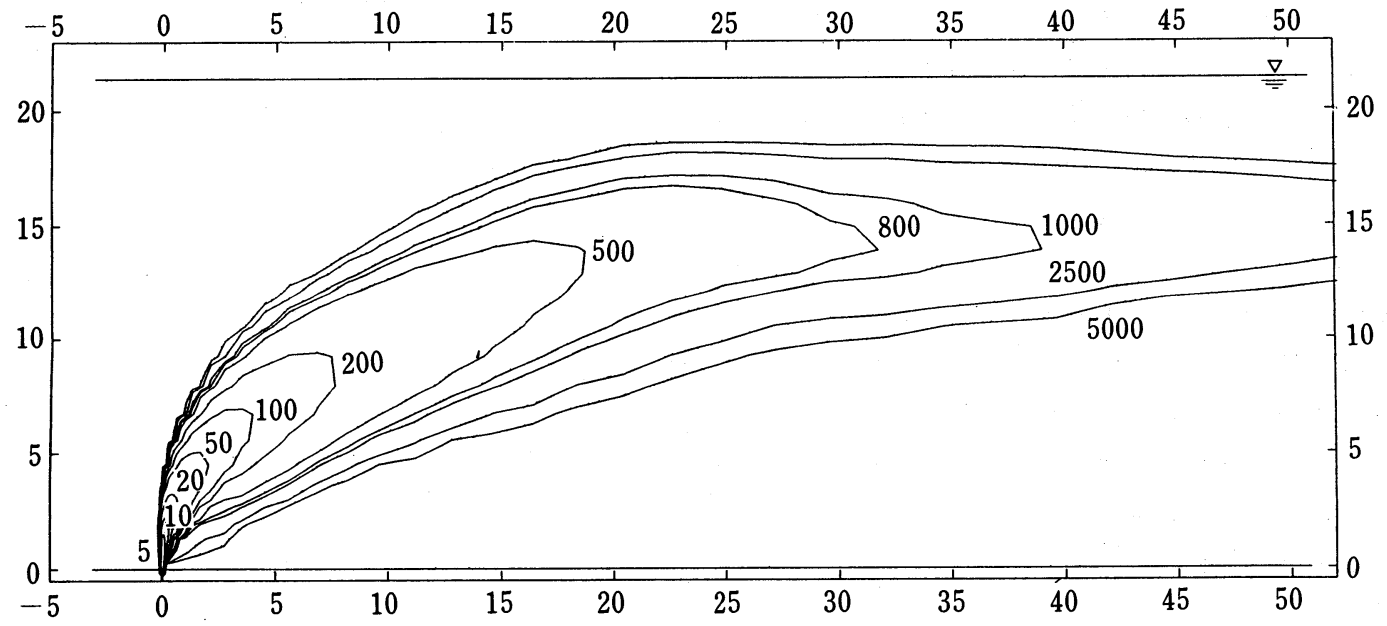

図-8 放出水濃度の縦断面分布（流水・成層域）
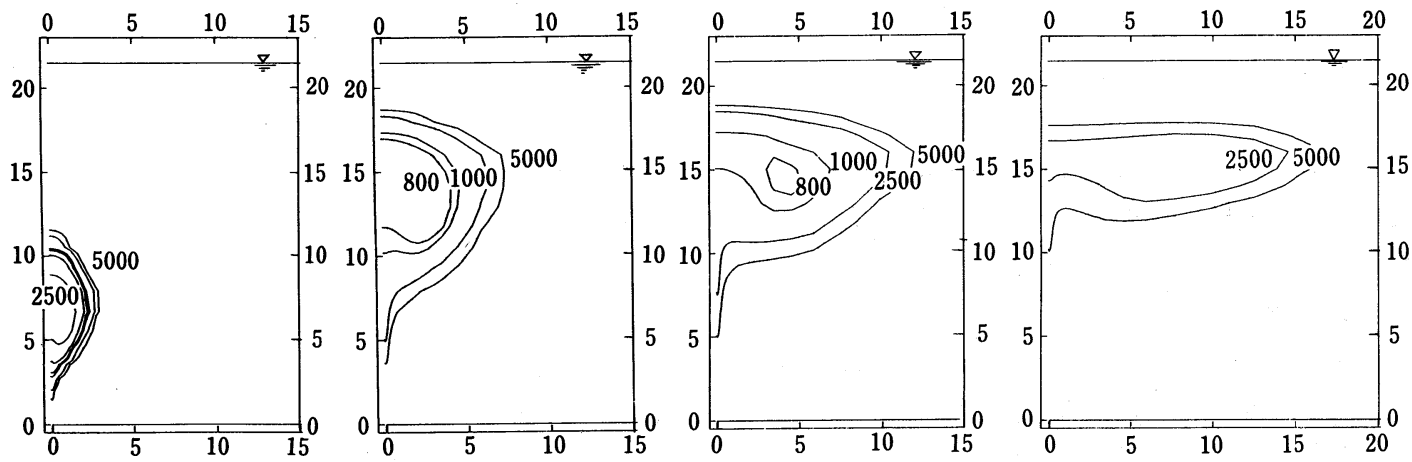

(1) $y=4.45 \mathrm{~m}$

(2) $\mathrm{y}=20.42 \mathrm{~m}$

(3) $y=29.62 \mathrm{~m}$

(4) $y=49.62 \mathrm{~m}$

圀一 9 ，放出水濃度の横断面分布（流水・成層域） 


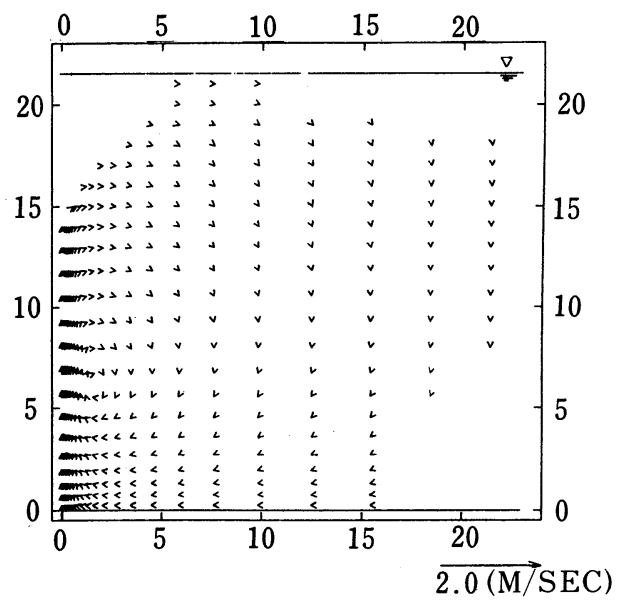

(1) 放出口近傍 $(\mathrm{y}=4.45 \mathrm{~m})$

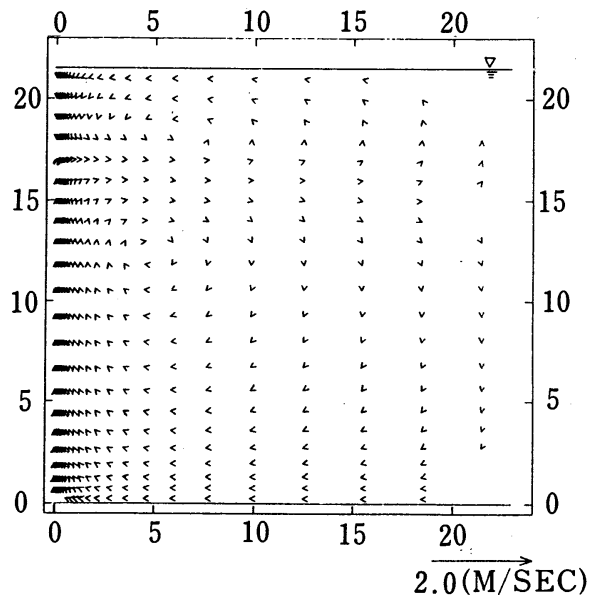

(2) 成層境界面到達後 $(\mathrm{y}=29.62 \mathrm{~m})$

図-10 流速ベクトル横断面分布（流水・成層域）

両者は同様の変化傾向をしている。一方，噴流幅およ

び厚さについては, 成層境界面到達後の両者の相違が 顕著となり，成層域の場合の方が非成層域に比べ，幅 が広く，厚さが薄くなる傾向が認められ，平面的に見 るとより偏平な断面形状となっていることがわかる。 5. おわりに

以上の結果より，本報で用いた平均值モデルによる 3 次元数值解析手法により様々な周囲水条件下に打け る鉛直重力噴流の拡散挙動を比較的精度よく, かつ包 括的に再現でき，その適用性についてす静水・成層域 および流水・非成層域については明確にすることがで きた。また，成層化した流水中へ放出される鉛直重力 噴流に対して本モデルを用いてシミュレーションを行 い，非成層域の場合との拡散特性の相違を明らかにし た。

今後は, 流水・成層場に打ける水理実験的研究を実 施するとともに，連続成層条件下での拡散挙動につい て解析検討していく予定である。

\section{〔謝辞〕}

本研究で用いた計算結果は, 東京電力株式会社の委

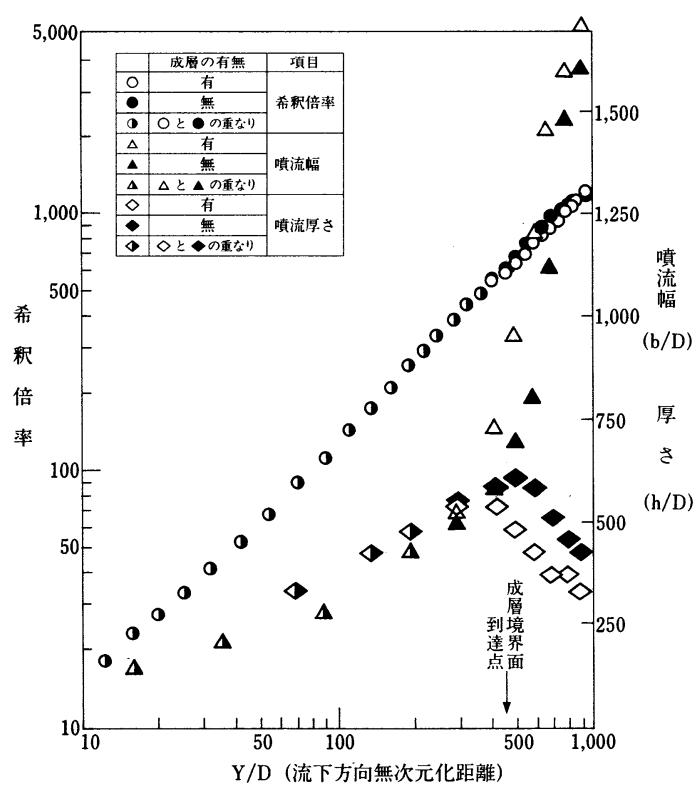

図-11 プルーム中心に沿う希釈特性, 噴流幅および 噴流厚さの比較 託によって実施した研究の一部である。また, 本計算作業にあたっては侏日本科学技術研修所の方々の協力 を得た。ててに記して，関係各位に対して深く謝意を表します。

参考文献

1) Wygnanski, I., Fiedler, H., J. Fluid Mech., vol. 38, part 3, pp. 577-612, 1969

2）石垣 博；日本機械学会論文集（B編），48 巻，433 号，1982

3）土木学会編，土木工学における数值解析/流体解析編， p p. 11-13

4）林・首藤；第 17 回海岸工学講演会論文集，pp. 355-359, 1970

5）水鳥・片野・和田；第 33 回海岸工学講演会論文集, p p. 581-585, 1986 